Morales et al. Fronts are ecotones but not diversity hotspots

\title{
Are oceanic fronts ecotones? Seasonal changes along the Subtropical Front show fronts as bacterioplankton transition zones but not diversity hotspots
}

\author{
Sergio E. Morales ${ }^{1 *}$, Moana Meyer ${ }^{2}$, Kim Currie $^{3,4}$, Federico Baltar $^{2,3 * *}$ \\ ${ }^{1}$ Department of Microbiology and Immunology, University of Otago, PO Box 56, Dunedin \\ 9054, New Zealand \\ ${ }^{2}$ Department of Marine Science, University of Otago, PO Box 56, Dunedin 9054, New \\ Zealand \\ ${ }^{3}$ NIWA/University of Otago Research Centre for Oceanography, PO Box 56, Dunedin 9054, \\ New Zealand \\ ${ }^{4}$ Department of Chemistry, University of Otago, PO Box 56, Dunedin 9054, New Zealand
}

Correspondance:

* Sergio E. Morales, University of Otago, Department of Microbiology and Immunology, 720 Cumberland Street, North Dunedin, Dunedin 9054, New Zealand

Email: sergio.morales@otago.ac.nz

*** Federico Baltar, Department of Marine Science, University of Otago, PO Box 56, Dunedin 9054, New Zealand

Email: federico.baltar@otago.ac.nz, Phone: +64 34795621

Running title: Fronts are ecotones but not diversity hotspots

Keywords: oceanic fronts /bacterioplankton / ecotone / Subtropical Frontal Zone /South Pacific Ocean 
Morales et al. Fronts are ecotones but not diversity hotspots

Ecotones are regarded as diversity hotspots in terrestrial systems, but it is unknown if this "ecotone effect" occurs in the marine environment. Oceanic

fronts are widespread mesoscale features, present in the boundary between different water masses, and are arguably the best potential examples of ecotones in the ocean. Here we performed the first seasonal study along an oceanic front, combining 16S rRNA gene sequencing coupled with a high spatial resolution analysis of the physical properties of the water masses. Using the Subtropical Frontal Zone off New Zealand we demonstrate that fronts delimit shifts in bacterioplankton community composition between water masses, but that the strength of this effect is seasonally dependent. While creating a transition zone where physicochemical parameters and bacterioplankton communities get mixed, this ecotone does not result in increased diversity. Thus unlike terrestrial ecotones, oceanic ecotones like fronts are boundaries but not hotspot of bacterioplankton diversity in the ocean. Ecotones are boundaries, or transition zones, between ecological communities, ecosystems, or ecological regions usually formed by steep environmental gradients (Kark 2013). In terrestrial systems, species richness, abundances and productivity tend to peak in ecotones (Kark 2013, Smith et al 1997). However, the study of ecotones and its effects in the open ocean environment has not received the same attention as in terrestrial systems, probably because transition zones are not as easy to detect as in land. The best example of ecotones in the marine environment is oceanic fronts. Fronts are areas where distinct water masses meet creating enhanced horizontal gradients of physicochemical properties (e.g. temperature, salinity) (Belkin 2003). 
Morales et al. Fronts are ecotones but not diversity hotspots

26 1987, Longhurst 2006), including increased phytoplankton diversity (Barton et al

27 2010, Ribalet et al 2010) and productivity (Belkin et al 2009, Okkonen et al 2004,

28 Springer et al 1996), yet their role in demarking bacterioplankton (i.e., defined as

29 bacteria and archaea) communities shifts is unclear. This is critical since heterotrophic

30 bacterioplankton make up the largest living biomass in the ocean, and drive oceanic

31 biogeochemical cycles, regulating the composition of Earth's atmosphere and

32 influencing climate (Buchan et al 2014, Kirchman 2010). Prior work revealed oceanic

33 fronts can act as ecotones, creating boundaries for bacterioplankton distribution in the

34 ocean (Baltar et al 2016a). However, limited sampling and strong seasonal variability

35 prevented testing of whether the front acted as a bacterioplankton diversity hotspot.

Here we performed the first seasonal high spatial resolution transect study of

New Zealand). This study involved 6 sampling cruises from January 2014 to April

2015. We combined a high-resolution characterization of the front (via a continuous

temperature and salinity recorder) and the analysis of bacterioplankton diversity

41 (based on 16S rRNA gene Illumina sequencing (see Supplementary Information)). In

42 all the cruises, bacterioplankton diversity and chlorophyll-a concentration was

43 sampled at eight surface (2 m) water stations along the $48 \mathrm{~km}$ long transect, following

44 the same approach as in previous studies (Baltar et al 2015, Baltar et al 2016a). The

45 Subtropical Front is where the warm and salty subtropical waters (STW) and the cold,

46 high-nutrient low-chlorophyll sub-Antarctic waters (SAW) meet. This front is

47 constrained along the SE continental shelf of New Zealand to about $40-50 \mathrm{~km}$

48 offshore, compacting the frontal zone to a width of 2-10 km (Heath 1972). 
Morales et al. Fronts are ecotones but not diversity hotspots

50 throughout the study, with the presence of the 3 main water masses located in this

51 area (Fig. 1A). Off the coast, the low salinity neritic waters (NW; characterized by

52 riverine inputs) encounter and gradually mix with the warmer and saltier subtropical

53 waters (STW). This is followed by a sharp (taking place in $<2 \mathrm{~km}$ between stations 3

54 and 5) drop in temperature and salinity, demarking the front and the convergence of

55 the STW with the offshore SAW. As previously reported in other studies across this

56 transect (Jillett, 1969; Heath, 1972; Shaw and Vennell, 2001; Hopkins et al., 2010),

57 the location, width and strength of the front oscillates seasonally (Fig. 1B) (Heath

58 1972, Hopkins et al 2010, Jones et al 2013).

A clear water mass dependent seasonal change in phytoplankton biomass

60 (chlorophyll-a) was observed along the transect (Fig. 2A). These blooms within the

61 STW coincided with the transition from the Austral winter (June-July 2014) to the

62 spring-summer seasons, as well as a smaller autumnal bloom. Observed chlorophyll-a

63 concentrations reached $>4 \mathrm{mg} \mathrm{m}^{-3}$ in December 2014 and $>2 \mathrm{mg} \mathrm{m}^{-3}$ in April 2015

64 during the study, in agreement with previous studies where the threshold of $>1 \mathrm{mg} \mathrm{m}^{-}$

$65{ }^{3}$ indicated bloom conditions (Hopkins et al 2010, Jones et al 2013). While strong

66 seasonality in phytoplankton biomass was detected in the STW, changes in the NW

67 and front were less pronounced, and absent within the SAW. This is consistent with

68 the characteristic iron-limited primary production of the high-nutrient low-chlorophyll

69 SAW (Baltar et al 2015, Jones et al 2013, Sander et al 2014). However, chlorophyll-a

70 concentrations where not higher within the frontal waters at any time point, with

71 values intermediate to those in STW and SAW, reflecting the mixing nature of fronts.

72 Changes in chlorophyll-a concentration were negatively correlated $(\mathrm{p}<0.01)$ to

73 bacterioplankton diversity (based on the Shannon Index), with fluctuations across the 
Morales et al. Fronts are ecotones but not diversity hotspots

74

75

76

77

78

79

80

81

82

83

84

85

86

87

88

89

90

91

92

93

94

95

96

97

transect modified by seasons (Fig2 B-D, and Tables S1-2). Changes in Shannon diversity were strongest across time (ANOVA F Ratio $=51.60$, $\mathrm{p}$ value $<.0001$ ), with no significant effect across the water masses $(p=0.45)$ unless time was accounted for (water mass $\mathrm{x}$ time: $\mathrm{F}$ Ratio $=5.13$, $\mathrm{p}$ value <.0001). While changes in bacterioplankton richness were observed and mirrored trends in diversity, it suggests that community structure (changes in evenness) where the strongest factor. Maximum diversity occurred during winter (June and July 2014) and the lowest in summer (December 2014). This inverse relationship between bacterioplankton diversity and phytoplankton biomass is consistent with the common negative diversity-productivity relationship found in aquatic ecosystems (Baltar et al 2016b, Smith 2007). This is specifically pronounced in areas with larger blooms (STW and the frontal waters) (Fig. 2D), which are the water masses with the strongest seasonal variations in chlorophyll-a and bacterioplankton diversity. Consistent with observations for phytoplankton biomass, bacterioplankton diversity did not peak in the front, with diversity values intermediate to those for SAW and STW.

Our results demonstrate that while fronts serve as ecotones in the sense of delimiting the distribution of bacterioplankton, their strength is not constant, but seasonally driven. This seasonality is linked to differences in phytoplankton biomass across the different water masses (e.g. December 2014). While oceanic fronts are clear boundaries, we demonstrate that they are not bacterioplankton diversity hotspots in contrast to observations for terrestrial plants. This might be due to the more dynamic nature of oceanic fronts, that experience continuous mixing, enlarging and contracting events resulting in a less stable environment than terrestrial ecotones. 
Morales et al. Fronts are ecotones but not diversity hotspots

98

99

\section{Conflict of interest}

100

The authors declare no conflict of interest.

101

102

\section{Acknowledgements}

103 We would like to thank the skippers and crew of the RV Polaris II for their help

104 during the sampling events. FB was supported by a University of Otago Research

105 Grant (UORG).

106

107

Supplementary information is available at The ISME Journal's website' at the end of

108 the article and before the references.

\section{References}

111 Baltar F, Stuck E, Morales S, Currie K (2015). Bacterioplankton carbon cycling along 112 the Subtropical Frontal Zone off New Zealand. Progress in Oceanography 135: 168113175.

114
Baltar F, Currie K, Stuck E, Roosa S, Morales SE (2016a). Oceanic fronts: transition zones for bacterioplankton community composition. Environmental Microbiology Reports: $10.1111 / 1758-2229.12362$.

Baltar F, Palovaara J, Unrein F, Catala P, Horňák K, Šimek K et al (2016b). Marine bacterial community structure resilience to changes in protist predation under phytoplankton bloom conditions. The ISME Journal 10: 568-581.

Barton AD, Dutkiewicz S, Flierl G, Bragg J, Follows MJ (2010). Patterns of diversity in marine phytoplankton. Science 327: 1509-1511. 
Morales et al. Fronts are ecotones but not diversity hotspots

126 Belkin I (2003). Front. Interdisciplinary Encyclopedia of Marine Sciences, edited by

127 Nybakken JW, Broenkow WW, Vallier TL: 433-436.

128

129

130

131

132

133

134

135

136

137

138

139

140

141

142

143

144

145

146

147

148

149

150

151

152

153

154

155

156

157

158

159

160

161

162

163

164

165

166

167

168

169

170

171

172

173

174

175
Belkin IM, Cornillon PC, Sherman K (2009). Fronts in large marine ecosystems. Progress in Oceanography 81: 223-236.

Buchan A, LeCleir GR, Gulvik CA, González JM (2014). Master recyclers: features and functions of bacteria associated with phytoplankton blooms. Nature Reviews Microbiology. 12: 686-698.

Heath R (1972). The Southland Current. New Zealand Journal of Marine and Freshwater Research 6: 497-533.

Hopkins J, Shaw A, Challenor P (2010). The Southland front, New Zealand: variability and ENSO correlations. Continental Shelf Research 30: 1535-1548.

Jones KN, Currie KI, McGraw CM, Hunter KA (2013). The effect of coastal processes on phytoplankton biomass and primary production within the near-shore Subtropical Frontal Zone. Estuarine, Coastal and Shelf Science 124: 44-55.

Kark S (2013). Ecotones and ecological gradients. Ecological Systems. Springer. pp 147-160.

Kirchman DL (2010). Microbial ecology of the oceans, vol. 36. Wiley-Liss: New York.

Le Fevre J (1987). Aspects of the biology of frontal systems. Advances in Marine Biology 23: 163-299.

Longhurst AR (2006). Ecological geography of the sea. Academic Press: New York, NY.

Okkonen SR, Schmidt G, Cokelet E, Stabeno P (2004). Satellite and hydrographic observations of the Bering Sea 'Green Belt'. Deep Sea Research Part II: Topical Studies in Oceanography 51: 1033-1051.

Ribalet F, Marchetti A, Hubbard KA, Brown K, Durkin CA, Morales R et al (2010). Unveiling a phytoplankton hotspot at a narrow boundary between coastal and offshore waters. Proceedings of the National Academy of Sciences 107: 16571-16576.

Sander SG, Tian F, Ibisanmi EB, Currie KI, Hunter KA, Frew RD (2014). Spatial and seasonal variations of iron speciation in surface waters of the Subantarctic front and the Otago Continental Shelf. Mar Chem 173: 114-124.

Smith TB, Wayne RK, Girman DJ, Bruford MW (1997). A role for ecotones in generating rainforest biodiversity. Science 276: 1855-1857.

Smith VH (2007). Microbial diversity-productivity relationships in aquatic ecosystems. FEMS Microbiology Ecology 62: 181-186. 
bioRxiv preprint doi: https://doi.org/10.1101/109868; this version posted February 20, 2017. The copyright holder for this preprint (which was not certified by peer review) is the author/funder, who has granted bioRxiv a license to display the preprint in perpetuity. It is made available under aCC-BY-NC-ND 4.0 International license.

Morales et al. Fronts are ecotones but not diversity hotspots

176 Springer AM, McRoy CP, Flint MV (1996). The Bering Sea green belt: ShelfDedge

177 processes and ecosystem production. Fisheries Oceanography 5: 205-223.

178

179 
Morales et al. Fronts are ecotones but not diversity hotspots

\section{$180 \quad$ Figure legends}

181 Figure 1. (A) Physicochemical changes in salinity (dashed) and temperature (solid)

182 along the surface waters of the transect in April 2015, as a representation of the

183 general structure of the water masses encountered in study region. The stations are

184 shown as vertical lines, with their predicted water masses given by colour. Salmon

185 pink $=$ Neritic Water $(\mathrm{NW})$, Green $=$ Subtropical Water $($ STW $)$, Blue $=$ Frontal Water,

186 Purple $=$ Sub-Antarctic Water $(\mathrm{SAW})$. This is an example of how the water masses

187 were in April 2015, but their location shift throughout the study. (B) Summary of how

188 the water masses shifted throughout the duration of the study, with sampling locations

189 shown in black.

190

191 Figure 2. (A) Chlorophyll-a concentration, and (B) bacterioplankton diversity

192 (Shannon index) in the surface waters along the transect in the six cruises performed

193 from January 2014 to April 2015. Different sampling cruises are denoted in different

194 colors, and the symbols denote different water masses. (C) Relation between

195 chlorophyll-a concentration and bacterioplankton diversity (Shannon index) with all

196 samples pooled together or (D) with samples separated by water mass. Neritic Water

197 (NW), Sub-Antarctic Water (SAW), Subtropical Water (STW), frontal zone

198 (FRONT). 
A.

St. 1

St. 2

St. 3 St. 4

St. 5

St. 6

St. 7

St. 8

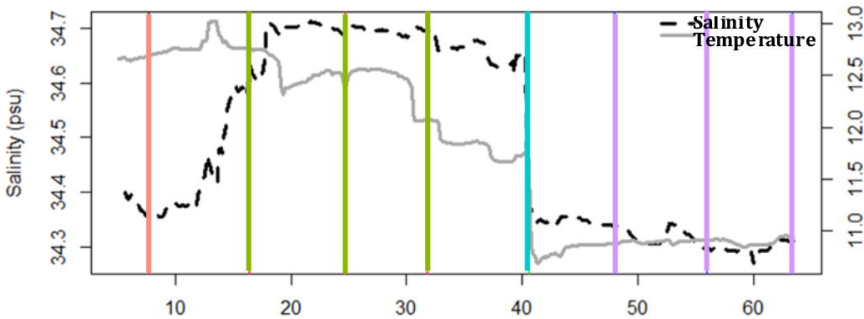

Water mass

B.

\section{Distance from shore $(\mathrm{km})$}

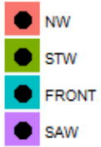

40C.

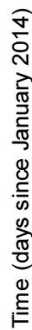

300

200.

100

0

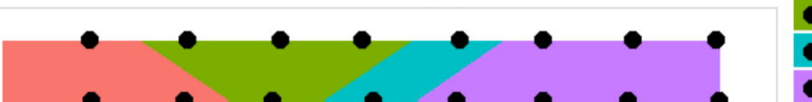

